\title{
Research on the Fusion of Enterprise Financial Accounting and Man- agement Accounting in the New Economic Situation
}

He Tang*

Canvard College, Beijing Technology and Business University, Gongzhuling City 136100, Jilin Province, China. E-mail:1178864067@qq.com

Abstract: In recent years, the Chinese economy has been developing rapidly, and the development model of market economy has been refined. Despite the continuous development of China's economy, it has also encountered many impacts and challenges. The survival of an enterprise is becoming difficult. For the sake of greater numbers of customers, Chinese enterprises need to improve their comprehensive competitiveness, reconstruct their internal structure, and optimize the development model, so they could remain invincible in the market. Under this background, Chinese companies need to adjust the development method of the accounting department, increase its management efficiency, and actively carry out transforming policies. The accounting department is not only responsible for financial accounting, but also for management accounting. It is necessary to integrate the two to promote the healthy development of the enterprise. Hence, in accordance with the current background of the new economy, the optimization of the financial accounting and management accounting and the integration of the two will be analyzed in this paper to ensure effective communication among financial management departments and promote the sustainable development of enterprises.

Keywords: Financial Accounting; Management Accounting; Integrated Development

\section{Introduction}

The analysis of management situation of the accounting department shows that the responsibility of the accounting department includes not only financial accounting, but also related management accounting. The management of the two has a deep influence on the development of enterprises ${ }^{[1]}$. In this new era, the environment of economic development is changing. If the financial accounting and management accounting of a company are completely separated, the company's comprehensive management capability will be negatively affected. The enterprise needs to systematically combine these two parts of the working responsibilities to achieve mutual coordination and common advancement.. In this case, the comprehensive management of corporate accounting would be more efficient, so that they could achieve the long-term development strategic goals of the enterprise.

\section{Principles of the integration of financial accounting and management accounting}

\subsection{Significance of integration}

Due to the conservative concepts of enterprise managers, there are still some defects with the internal financial 
management mode of some enterprises in China. Such defects affect the operation and development of the enterprise. To solve these problems, Chinese enterprises need to promote the integration of financial accounting and management accounting. Relevant personnel need to strengthen the integration between financial accounting and management accounting according to the new economic environment.

\subsubsection{Positive influence on financial accounting and management accounting}

In recent years, the financial accounting and management accounting have become an important driving force to accelerate the development of an enterprise, which has diversified the market economy model. With the improvement of information technology, enterprises have applied advanced computer technology to financial management. Enterprises have to deal with a lot of data in the process of production, operation and management. With the continuous accumulation of data, enterprises need to extract valuable information from the massive data information, which is a crucial task in the whole enterprises management. Therefore, to satisfy the needs for broader market, an enterprise needs to strengthen the integration of financial accounting and management accounting to ensure the interaction between financial accounting and management accounting.

\subsubsection{Positive influence on enterprise development}

At present, China is gradually constructing a perfect modern management theory system, and the complete system of Chinese enterprises has been established. However, there are more and more overlaps between the working responsibilities of various departments within one single enterprise, and the independence of those departments is gradually reduced $^{[2]}$. If an enterprise wants to achieve its overall development, it needs to focus on coordination and close combination of financial accounting and management accounting. The operation and management of enterprises requires the interaction among different departments, so the communication on an issue may involve multiple departments, and it will be complicated and difficult to complete such communication. Therefore, in order to develop as a whole, it is necessary to establish harmonious cooperative relationships among various departments to strengthen integration of the whole enterprises.

\subsection{Principle of integration}

\subsubsection{Gradual principle}

For many Chinese enterprises, there are great difference between financial accounting and management accounting, so it is necessary to take the time to promote the integration of the two. Neither pushing that process hastily nor ignoring the integration brings positive influence on enterprise development. Instead, an enterprise needs to ensure the slow but steady development of the integration according to the relevant laws and the actual progress of the integration of the two working responsibilities. In this case, the enterprise can avoid the contradictions and risks in the integration of the two. Moreover, it is also necessary to construct a scientific integration model that covers detailed integration measures is needed to ensure the stability and continuous integration of the two working responsibilities.

\subsubsection{Principle of complementary integration}

Despite that both financial accounting and management accounting are accounting jobs in essence, an enterprise should ensure full consideration of the long-term changes of both. Based on accurate understanding of the connotations of financial accounting and management accounting, enterprises could ensure appropriate integration and complementarity while respecting differences. In that case, the enterprises could improve the efficiency of financial management, which will bring more economic benefits for enterprise. In addition, the enterprises could undertake more social responsibilities, help the healthy development of the whole market, and contribute to the stable development of the national economy.

\section{New problems in the integration}

\subsection{Conflicts between modern management and financial management systems}

For a long time, Chinese enterprises have adopted the traditional financial management mode. Those enterprises mainly focus on the business of the enterprise to collect and short out the corresponding financial data through mobile 
phones. That is to say, they depend on simple analysis of financial data integration. Based on the traditional financial data of the enterprise, they could regulate and supervise the financial activities. However, after the modern financial management models are constructed, many traditional financial management are found to be defective because they no longer meet the current needs of enterprise development, especially the needs for investment and management, so they will further has a negative impact on the long-term development of enterprises.

\subsection{Lack of management awareness}

An enterprise need to check the financial data, and regulate the implementation of financial management through the supervision mechanism in accordance with the financial management system. Moreover, the financial data of an enterprise directly reflects the financial development of the enterprise and helps with accurate predictions about the future development of the enterprise ${ }^{[3]}$. However, due to the lack of management awareness of the accounting managers, many enterprises ignore accounting and focus on promoting the development of their enterprises. In that case, the accounting managers merely concentrate on simple analysis of statistics, but do not conduct in-depth analysis of statistics.

\subsection{Lack of professional talents}

At present, the education management of the accounting management majors and the relevant courses related to financial accounting management are still defective in many universities. So, those universities have not provided enough graduates majoring in social financial accounting management. Although some colleges and universities have gradually realized the importance of the financial and accounting management profession and have set up related majors and courses, they have neglected the cultivation of students' practical ability, resulting in insufficient comprehensive capabilities of financial accounting management staff. That will restrict the improvement of corporate financial accounting management capability.

\subsection{Low level of accounting informatization}

At present, the rapid development of science and technology in China brings many new technical equipment, which are gradually applied into more and more enterprises. Because most financial managers ignore the importance of financial accounting data analysis, they have not formed a data analysis system and cannot fully integrate their own business management. The majority of the managers mainly rely on management software to cope with financial management, resulting in a decline in the integrity of financial accounting management.

\section{Advice on integration of financial accounting and management account- ing}

\subsection{Improve the management system}

For the sake of better management of financial accounting, an enterprise needs to establish a financial accounting management system that is compatible with it, and to stipulate the details of the management measures. For the sake of better integration of financial accounting and management accounting, the enterprise needs to establish a sound financial accounting management system within the enterprise, to enroll excellent management talents, optimize the allocation of responsibilities among departments, and avoid mutual prevarication. Moreover, it is necessary to strengthen the contact and communication between departments and refine the comprehensive management mode of the enterprise.

\subsection{Establishing correct accounting concepts}

For the sake of efficient management of financial accounting, the staff in accounting departments needs to master more concepts about financial accounting management and know about the importance of the integration between financial accounting and management accounting. Therefore, enterprises need to accurately perceive the essence of financial accounting and management accounting, formulate a reasonable integration model and implement effective policies to promote the integration. In that case, the enterprises could benefit more from the integration of financial ac- 
counting and management accounting. The current economic development environment determines that financial accounting management has become an important driving force for the current enterprise development. Correct accounting concepts will enable accounting staff to optimize their working performance and to ensure reasonable allocation of accounting works, so the efficiency of financial accounting management can be improved. In addition, it is necessary to ensure in-depth analysis of accounting data to help enterprises establish scientific management models.

\subsection{Pay attention to the training of professional talents}

For the sake of more competitiveness in the market and efficient management of financial and accounting, an enterprise has to depend on professional talents majoring in financial and accounting management. Therefore, an enterprise needs to enroll professional talents and to establish a talent training mechanism. For modern enterprises, human resources play a vital role in financial accounting and management accounting. Managers should grasp adequate knowledge about accounting, collect rich experiences in financial accounting, to update their perception of the current market environment from time to time, to accurately predict the development of their enterprise in the future, and help companies improve the scientific and effective decision-making. Therefore, plenty of colleges and universities need to set up more courses related to financial and accounting management, and to promote the cooperation between schools and enterprises. In that case, the ability of accounting majors could be cultivated according to the expectations of the employers. In addition, it is necessary to refine the theoretical system of financial accounting management on the basis of practical accounting management. Moreover, it is necessary for the human resource department in an enterprise to optimize the talent recruitment mechanism and to establish a sound talent training mechanism to make the best of the talents' competence to increase the efficiency of accounting management and to accelerate the development of the enterprise.

\subsection{Applying modern accounting information technology}

At present, the technological research and application in China has been developing rapidly, and the hi-tech equipment and relevant technology plays a crucial role in the development of enterprises. Those technology and equipment are helpful for enterprises to improve the efficiency of enterprise comprehensive management, which will be crucial for the long-term development. In order to further promote the integration of financial accounting and management accounting, an enterprise needs to accurately perceive the accounting functions, to apply modern accounting information technology so they could ensure stable and sustainable development of enterprises.

\section{Conclusion}

In summary, the financial accounting management of modern enterprises includes financial accounting and management accounting, which influence and interact with each other. In fact, financial accounting management and management accounting are different in objects and the specific measures, so the application of single management theory is not enough to ensure high efficiency of the two kinds of management. For the overall development, an enterprise needs to strengthen the integration of financial accounting and management accounting in accordance with the environment of economic development, to summarize the specific problems of enterprise financial management. In accordance with the development status of the enterprise, the enterprise needs to find out the solutions to those problems to achieve the strategic goals of the whole enterprises.

\section{References}

1. Mantona R, Raub H, Fahyb F. Using mental mapping to unpack perceived cycling risk. Accident Analysis \& Prevention.2016; (88): 138 - 149.

2. Fang SK, Shyng JY, Lee WS, et al. Exploring the preference of customers between financial companies and agents based on TCA. Knowledge-Based Systems, 2017; (27): 137 - 151.

3. Faulkender, M and M. A. Petersen. Does the source of capital affect capital structure. Review of Financial Studies, 2018; 19(1): 5 - 79 . 